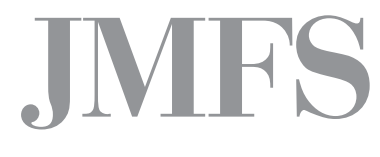

Journal of Management and Financial Sciences
Volume XIII

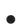

Issue 40 (March 2020)

pp. $43-56$

SGH Warsaw School of Economics

Collegium of Management and Finance

Savvas Zachariadis

Department of Balkan, Slavic and Oriental Studies

Faculty of Economic and Regional Studies

University of Macedonia

Thessaloniki, Greece

ORCID: 0000-0002-4066-072X

\title{
Financial crises and the perils for the world economy
}

\begin{abstract}
In this paper, we wish to address the issue of financial crises. We focus on the causes and implications for the world economy and financial stability. For this reason, we attempt to identify the relative phenomena that encourage the emergence of financial crises. The amplification of the financial sector at the international level and the high degree of financial integration render the debate of financial crises solemnly significant. The world economy has become unstable and vulnerable to the emergence of unanticipated financial events. Such events are not simply limited to a large bank default but also to the inability of a multinational firm or an agent to validate their debts. Thus, we mainly emphasize the insights of Hyman Minsky into the global financial crisis, who suggested that the flaws of the current dominant financial status would eventually entail instability and probably lead to crises with contagion effects at the international level. Therefore, the aim of this paper is to indicate that the perils of financial crises for the global economy must be perceptible and considerable ex ante in order to be successfully confronted.
\end{abstract}

Keywords: financial crises, instability, world economy, financial cycle, Minsky

JEL Classification Codes: G01, F65, E44, B26 


\section{Introduction}

The concept of financial crisis and instability has been a matter of controversy. We highlight the main causes of financial crises and their implications to the global economy. Thereby, firstly we address the role of banks, the aspects of innovation, speculation, and crisis contagion. After that, we present in great detail the theory of Hyman Minsky in order to comprehend the movements of the financial cycle and its relation to financial crises. In the third part of the paper, we provide relative empirical evidence. The examination of the history of financial crises constitutes a useful lesson to comprehend the whole issue. Peterson states that "leaving history out of analysis indicates a false sense of determinacy and predictability to economic process" [1977, pp. 202, 213-214]. History and financial crises proffer an interesting learning method. However, history customarily describes unprecedented events. In the case of financial crises, though, their history is often repeated. Besides, we cannot neglect the trajectory of financial cycles. Thus, we empirically refer to the events of two recent financial crises, the East Asian financial crisis in 1997 and the US subprime crisis in 2008. Hence, in the last part, we gather the arguments and conclusions.

\section{Causes of financial crises and instability}

The actual function of the financial system could be described as a dynamic system that endogenously generates instability and cyclical movements. Instability and fragility of the financial system may result in a financial crisis. Even if the financial crisis is not associated with a general economic crisis or recession, notwithstanding the consequences to economic activity are significant.

Financial crises are the outcome of globalization, free capital mobility, increased interdependence in international financial relations, and deregulation. During periods of credit expansion, similar phenomena were observed. Irrational exuberance, extreme laxity in financial regulation and too much available credit, altogether put at risk the international financial system. McKinnon and Pill [1997] have named it 'The Over-borrowing Syndrome'. Krugman [1998] suggests that over-lending and over-borrowing produce a moral hazard issue. Sau states that the financial system is a complex one and that renders it unstable where "group dynamics can fuel speculative bubbles in asset markets and attitudes toward risk, which in turn can lead to financial fragility and instability" [2013, p. 14]. Borio and Disyatat [2011] associate financial distortions with what they call the 'excess elasticity' of the system. By the term excess elasticity, Borio and Disyatat imply the incapability to limit credit and asset prices expansions which lead to the creation of financial instabilities and crises. Borio and Disyatat also raised the issue of 'excess saving' view, where global current account surpluses could generate a financial crisis by financing the credit boom in deficit countries. Hence, the excess 
of saving over investment puts downward pressure on world interest rates. As a result, characteristics of an upcoming global financial crisis are observed, such as credit expansion even in more risky assets. Furthermore, Eichengreen and Arteta (2000) in their analysis of credit expansion found that a growth by $1 \%$ in the domestic credit rate would raise the likelihood of a banking crisis by $0.056 \%$ in the following year.

\subsection{The role of banks in financial instability}

The financial cycle contributes to banks' failure, whereas the capital inflows during an economic expansion lead to increases in prices of assets, stocks, real estate and thus to currency overvaluation. In general, financial crises reduce agents' confidence in the banking system that has been engaged in excessive risk-taking activities. Banks usually tend to refinance the liabilities by issuing credits and loans, rendering themselves vulnerable in cases of adverse financial circumstances. Banks do not simply record the loans they grant in their balance sheets, but furthermore, they trade them in the open market. Thus, they sell loans in order to acquire more funds and tend to gain profits from any new transaction. Additionally, they are also involved in liquidity or money creation by lending their own IOUs to borrowers. The main issue is if this liquidity is only feasible and visible during the boom phases, but as soon as a crisis is near, then it disappears at once. Consequently, this illusionary liquidity would be transformed into debt burden to the shoulders of some agents, central banks or even governments.

Financial instability arises when there is no explicit distinction of roles between the operation of commercial and investment banks. ${ }^{1}$ Commercial banks could provide shortterm and low-risk loans to firms and households taking all the precautions for repayments. Investment banks usually tend to finance positions in capital assets for future earnings and they could be allowed to have a more long-term, risky attitude. However, commercial banks should not be allowed to take on risky positions, since they assist firms and households' activities and, not to be forgotten, that they could resort to the central bank in the case of a liquidity shortage. Commercial banking is a vital function of the domestic economy, which develops an active financial role abroad, too, contributing to the public-private purpose they are supposed to serve.

1 The Glass-Steagall Act in 1933 introduced that distinction in response to the 1929 crash. It established a regulatory distinction between commercial and investment bank activities and prohibited proprietary trading by retail banks. The Act was abolished and replaced by the Gramm-Leach Bliley Act, which removed these constraints, with the justification that banks should be allowed to mottle their activities. However, the US subprime crisis of 2007 portrayed the ineffectiveness of the new Act and afterwards a new role, the Volcker rule, was established, separating investment banking from consumer lending. Nevertheless, the Volcker rule is not similar to the Glass-Steagal Act because it permits various exceptions. 


\subsection{Securitization}

Another important aspect of world financial instability is securitization, which comprises the process of pooling loans, mortgages and issuing securities. Stiglitz quotes that "securitization had the purpose to insure by diversifying risk, so each investor would bear little risk, but instead, securitization, as designed and practised, ended up being just one more amplifier of the crisis" [2018, p. 9]. Securitization, in association with globalization, has contributed to financializing the global economy by throwing numerous new financial products in the global market.

Narrowly defined, securitization consists of the convertibility of loans into securities, tradable to open markets often via off-balance sheet. Minsky argued that "whatever can be securitized, it will be securitized" [1990, p. 64], implicitly highlighting the magnitude and prospects of the amplification of securitization. In the context of large securitization, the success of monetary policy to cope with a crisis is rather doubtful. There are many non-bank financial institutions that constrain the range of policy implementation by monetary authorities. Thus, central banks can protect only one part of the financial system lessening its efficiency. That facilitates the endogenous money supply growth. The financial system becomes vulnerable and unstable. The issue is that in times of contraction (wage contraction, private consumption, saving, or aggregate demand), the promised increased money could not be easily validated, also producing a potential domino effect. Therefore, securitization deepens the problem of financial instability and renders its remedy more complex.

\subsection{Innovations}

At first glance, the term innovation entails a positive sense and there could be little or no connection with financial instability. Schumpeter [1934] stressed the mechanism of innovation as a means of growth and structural change. Economic growth is the outcome of innovation, which specifically means the adoption of new combinations of materials and productive methods or the introduction a new product or a market. Innovation may lead to super-profits or a breakdown of a firm or an entire sector. Schumpeter named innovations as 'creative destruction of the system', since innovation rewards profits on the one side, but also destroys competitors on the other side.

In the financial sector, innovations offer the opportunity for banks to increase profits and to decrease costs. By innovations in finance we mean the introduction of new financial products and instruments such as futures contracts, derivatives, interest rate swaps, credit default swaps, etc. They are driven by international competition that contributes to increasing leverage and liquidity of financial instruments. However, when a crisis is forthcoming, this liquidity appears to be fictitious. Minsky [1992] refers that during prosperity periods of expansion, innovations in finance will grow endogenously urged by success. Brock et al. [2009] have demonstrated that 
financial innovation may destabilize the financial system. Additional research has shown that innovations increase price fluctuations resulting in destabilization and a reduction in average welfare [Hart, 1975; Citanna and Schmedders, 2005]. Mastromatteo and Esposito underline that "more innovations yield more profits but also more instability because the longer the bubble is allowed to grow, the higher financial leverage becomes, and thus innovation, investment, uncertainty, and financial bubbles are one and the same thing" [2016, p. 30]. On the contrary, at periods of low financial innovation, the financial system is more stable.

Financial innovations have increased credit expansion and risk. Certainly, they are important for investments and reproduction of economic growth. It could be argued, though, that most of recent financial innovations were related to financing positions in financial assets and hence, with speculating on the fluctuations of prices of those assets. The above process had little to do with investment production and economic growth. The stability and the proper function of the financial system are essential, and therefore, the main concern is that innovations may produce instabilities. Since they are innovative, then we are unaware of their implications to the economy. Unambiguously, there is a shortage of knowledge and experience on how they will operate in the market. They tend to modify the structure of the financial system because they accelerate the speed of the financial cycle and increase the size of the financial sector.

What is more, innovation is linked with regulation. It enables financial institutions to escape from regulatory controls. Additionally, institutional rehabilitations have always been left behind with innovations, providing the scope to take full advantage of these steady retards. In the absence of constraints, the financial system in search of profits will inevitably lead to innovation. Some innovations were also passed to non-banking institutions, or to the shadow banking system, which is not subject to the banking regulatory context. The degree of regulation, therefore, accelerates or not the process of innovation.

However, we need to reiterate that the term innovation is not associated with distortions and undesired events. By contrast, it is more than desirable when innovation brings more quality, customer service, technological progress and sound economic prosperity, contributing to general welfare. In the current era, though, innovation has been linked with the outsourcing of labour activities, wage and benefits reduction, inflated bubbles, financial amplification and instability.

\subsection{Speculation}

Speculative attitudes are often met in the international financial field. The global financial market has inevitably attracted fund managers, enhancing the arbitrage and speculative transactions. Profits are generated but they do not contribute to productive long-term investment that serves total output and employment. By contrast, they add to financial instability and cyclical movements in the economy.

An international speculative practice to exploit differences in rates among countries is termed as currency or interest rate carry-trade strategy, i.e. borrowing low and lending high. 
This tactic perquisites that interest rates on debt have to be lower than interest rates on assets. Speculation is seen as an attempt to forecast the market's psychology. Speculators usually move against market trends for profits anticipation and as soon as they invest in an asset, they have already their expectations set. It is true that they bear risks with their attitude and in this point two main issues need to be questioned. First, how covered in terms of liquidity and finance reassurance are they in case of losses, and secondly, when they take a position against market trends and put a lot of capital in their investment, do they possess the same information as anyone? The first question needs to be addressed to the financial institutions, which provide funds for their investments based on guarantees, and to official regulatory authorities. The second question, if such a case ever occurs, constitutes a financial market failure as well as governments' failure to verify and assure a fair financial system. If the stability of the financial market were the perquisite, then the essential situation would be the existence of a large number of speculators with different options, expectations and investment decisions.

\subsection{The contagion of a crisis in the world economy}

Most of the financial crises are likely to become international. There are contagion and spread effects arising mainly from international trade and financial linkages. A connection among countries is that arbitrage links national markets. That is because the determinant factor is the amount of the leverage of speculators and the vulnerability of these markets. Contagion and spread effects, apart from arbitrage in products, also encapsulate securities and money transactions. The interaction of identical monetary policies among countries as well as the level of domestic money supply and interest rates may facilitate or prevent the spread of an international financial event.

A significant reason for the emergence of contagion could just be the psychology of agents. Perceptions, norms, and attitudes of agents are affected by other investors' actions. When an attitude changes as far as the price of an asset is a concern and everyone wishes to sell, it is likely to spread that behaviour internationally, even resulting in a liquidity need. Hence, the main concern would be the magnitude. Even if there is insolvency avoidance or deposits guarantees policies, these cannot be sufficient in cases of a contagion crisis at the international level. The reason is the liquidity shortage and thereafter, a vast amount of funds will be required, since all products and financial transactions are internationally traded and cleared. Consequently, in the absence of a multinational coordinated lender of last resort intervention, domestic monetary safeguards are still prone to unanticipated financial events.

Furthermore, many countries throughout the world run large budget deficits and debts that are held primarily by international financial institutions and thereafter, by other government or international organizations. What if one huge institution breaks down, or a country with a huge national debt could not meet its repayment requirements? From this point on, contagion and spread effects will appear to other countries and financial institutions due to high interdependence. If banks and other financial institutions were isolated units, then 
contagion will never apply. However, the interbank system, capital mobility, credit expansion render the default of one big financial institution extensive. Apart from international financial economies, whenever a financial disruptive event takes place, the implications are not limited to the financial sector. In fact, the financial sector carries away other sectors of the economy such as consumption, saving and employment. What was initially a financial distress might trigger a wide economic crisis and recession.

\section{The Minskyan financial cycle}

Minsky can be considered as a theorist of the financial system. He incorporated banking and finance in his theory because credit and debit are essential to the development process. He delineated cyclical trends to analyze the transformation of an economy over stages with changes of expectations and behaviour. Minsky outlined the movement as "success that breeds excess which breeds failure" and "the more things change, the more they remain the same" [1993, p. 2]. He urged about the endogeneity of cyclical instability and the transitory nature of the institutional underpinnings of financial markets.

Minsky [1986] described the endogenous process in an inherently unstable and flawed economic system, whereby self-interest behaviour predominates in complicated financial connections. He argued that economic stability leads to instability, termed as the 'paradox of tranquility', whereas investment volatility constitutes the main cause of financial instability. The current economic system is dependent upon investment and when the latter is no longer applied due to limited financing, then crises will emerge. Minsky mentioned that the financial system influences investment in an economy by determining a demand price level for investment goods. Even though the neoclassical theory assumed the economy as a barter economy, with the rest of variables adding up to the main model, Minsky regarded that the actual economy is rather driven by the pursuit of financial profits, where production precedes market exchange, and finance precedes production. Additionally, it contributes to the production and investment costs within the use of external financing, since the creation of liabilities will require future repayment. Thus, the expected gains from production and investment must be adequate in order to validate the forthcoming debt. Bearing in mind the uncertainty factor, there are no adequate guarantees for sufficient profits, thereby increasing both borrowing and lending risks. Eventually, these risks will diminish the supply and demand for investment goods, swaying investment as well.

According to Minsky's Financial Instability Hypothesis (FIH), the financial system is unstable and becomes even more fragile in euphoric periods. The FIH describes the cyclical movement from expansion to contraction where "the economy transits from financial relations that make a financial system stable or unstable" [1992, p. 8]. Modern economy begins with negotiations between owners of financial institutions and entrepreneurs/businessmen to finance their investment for making future profits. The gist of the recent economic 
operation is the exchange of present capital to future, whereas present capital is used for current investment in production and future capital represents profits accrued to repay past loans. Thus, profits and investment are complementary, since one brings the other. Changes in the level of profits will then have a strong impact on the level of debts, in the prices of assets and mainly in the capacity of borrowers to pay off past loan obligations. Therefore, in the actual economy the past, the present and the future are linked through production, profits and financial interdependencies.

Minsky implied that the financial system could contain hedge finance, speculative or Ponzi financing. If it consists only of hedge finance, then the financial regime will be stable, otherwise unstable. When hedge finance appears, dominant positive expectations also emerge, implicitly inducing all participants in the financial system to be engaged in more debt. Minsky [1986] reflects on the process where financing shifts from 'hedge' to 'speculative' and, eventually, to 'Ponzi'. Initially, at the hedge phase, enterprises usually adopt a conservative approach to financing and they are viable enough to meet their debt payments, both the interest and principal. Nevertheless, as the economy expands, enterprises are willing to increase their debt levels, since higher profits are coming and consequently, they require more capital. Such success encourages other agents to imitate similar behaviour. According to Minsky, the financial system has now moved to the speculative phase, where borrowers could only validate the interest payment but not the principal and thus they must roll over the financing with another loan. The acquirement of more profits attracts more and more agents and enterprises, driven up indebtedness to the level where eventually refinancing is merely needed to make interest payments. That is the phase of Ponzi finance, where agents and firms must borrow even more to make interest payments on their existing liabilities [Minsky 1982, 1986]. The Ponzi finance cannot meet either the principal or the interest and the options left, except for new borrowing, are to sell assets or dividends, lowering the margin of safety. At the end of this period, credit is getting more limited, liquidity is reduced, deleveraging begins, highly indebted firms and agents can no longer meet their payments and break down, spreading contagion effects to other firms, agents, financial institutions. The speculative phase signifies a boom, whilst the Ponzi phase a recession.

The fundamental assertion of the FIH is that "the financial structure evolves from robust to fragile over a period in which the economy performs well” [Minsky, 1991, p. 16]. The peril of financial instability stems not only from the debtors but most importantly from creditors. It is the fear that creditors cannot cope without the expected payments. Minsky formulated his main recommendations in the 1980s but remains relevant. He cleverly wondered "where is the cash flow?" [Minsky, 1986] in order to delineate money circles of past debt arrangements that would affect present and future payments. 


\subsection{The East-Asian financial crisis}

In this section, we wish to provide brief empirical evidence from two financial crises that resemble the above arguments and the Minskyan financial cycle. The East Asian crisis encapsulates all the characteristics of an unstable international financial system. The crisis originated in 1997, when Thailand announced that it could not meet its foreign debt obligations. Thailand, Malaysia, and Indonesia presented a magnificent increment in stock and real estate prices in industrial activity, whilst trade deficits enhanced. There was a rapid economic growth resulting from outsourcing by US, Japanese, European firms and certainly by foreign capital inflows [World Bank, 1997], mainly coming from Japan. Also, Japanese and European bank loans were granted to East Asia countries, contributing to current account deficits growth. The outsourcing process was obvious in East Asia markets, since major multinational enterprises were seeking to abridge their labour costs. In the case of Thailand, Indonesia, Malaysia, and South Korea, they had all experienced a deregulation process, whereas financial institutions at the same time lent foreign currencies and all of the sudden, they stopped.

By the end of 1996, the new emerging financial firms in Thailand started to incur large losses on their loans. Then, foreign lenders were worried about the value of their loans to domestic borrowers and capital outflows ensued. Initially, the central bank of Thailand defended the domestic currency, but as soon as reserves could no longer be available, then a sharp devaluation began. Within six months, the devaluation process initiated a contagion effect to foreign exchange values of each of the currencies of East Asian countries, except for the Japanese, Chinese and the Hong Kong dollar. In that period, it was estimated that equity losses accounted for $\$ 700$ billion [Greenspan, 1998], whilst equity markets in Thailand, Indonesia, Malaysia, the Philippines and South Korea underwent an abatement, in local currency terms, by 53\% to 76\% from their 1996 and 1997 ceilings [Chote, 1998, p. 2]. The forthcoming result was a reduction in prices of stocks, real estate and bank failures. The IMF intervened to stabilize the financial crisis by inducing East Asia governments to balance the current accounts by cutting expenditures. The East Asian crisis influenced the global financial system, where spillover contagion effects of the financial disturbance across countries ensued, due to export trade links and financial interdependence, also fuelled by the fact that the region's currencies were pegged to the US dollar.

The empirical lesson from the East Asian financial crisis is the fact that whenever a currency value rises because of capital inflows expansion in association with current account deficits, then this combination renders the country vulnerable, since the economies are overheated. As soon as the euphoria climate of capital inflows can turn into a liquidity shortage, that would result in a sharp currency depreciation. That was exactly what happened there, as soon as liquidity, initially from capital inflows, had stopped, then psychology changed and the financial crisis started to unfold. 


\subsection{The US subprime crisis}

The global financial crisis of 2008-09 initiated from the US subprime crisis and spread to the rest of world by means of capital flows, and certainly through expectations. Similar characteristics could be found in the Great Depression in 1929-33, but now the difference consists of the time of international transmission, which was sooner due to advanced information technologies. However, the status of then and now is much alike in terms of financial instability.

The Minskyan financial cycle was apparent in the US subprime crisis, where the boom phase commenced with an enhanced securitization of mortgages, mainly debts, as a result of the introduction of financial innovations and the bubbles in the real estate sector. However, here again financial deregulation had advanced in the US economic environment during the 2000s and there were also capital inflows to the US economy, all factors that had facilitated the boom period. However, the flame was initiated by an unstoppable mania of securitization that financial institutions had put forward, without reassuring relative hedge positions. When more and more agents engaged in easy credit, then only a match was the missing element to light up the flame of a financial crisis. The US government, to cope with the crisis, decided to move towards an expansionary fiscal policy that restrained the negative effects. The expansion of the fiscal policy, in this case, offsets the reduction in consumption and investment and improves the overall economic activity. The US subprime crisis also brought up the issue of contagion, coming from a country advanced financially, which would inevitably affect the global financial system.

\section{Summary}

In the current era, we notice that the international economic system has been developing in a more complex manner driven by financial amplification. We could argue that the global economy has been financialized. We have outlined two recent financial crises which turned to be international. The crises have highlighted the weaknesses, inefficiencies and insufficiencies of domestic financial systems and, at the international level, the inadequacy of the international monetary and financial system. The repercussions of the East Asian crisis and the crises of the $21^{\text {st }}$ century are a matter of much debate and analysis. We can argue, though, that actual financial crises are much affected and related to globalization. Financial distortions may arise from rapid credit expansion and high levels of capital accumulation. The presence of debt and capital accumulation in specific sectors deteriorates the recovery.

The essential implication is the identification of causes that render the financial regime either stable or unstable, in order to prevent instability and forthcoming crises. According to Minsky, the crucial destabilizing phase of the cycle moves upwards. Therefore, what really 
matters in the real economy is the amount of all liabilities, loans and credit structure, and certainly asset holdings not only for the current period but most importantly for a longer period. The latter phenomenon is significant, since the shift of the economy towards fragility and imbalance does not take place all of a sudden but is the result of an accumulated event. Thus, it is necessary to observe whether the amount of actual circular income is sufficient to repay past loan obligations. If the answer is affirmative, then a financial regime is regarded stable, otherwise serious distortions are emerging. The financial instability hypothesis implies that the economy could easily shift from hedge to speculative in times of euphoria. This takes place either in forms of risk aversion, reductions in margins of safety, since profits are created, short term credit is easily accessed and there is a strong incentive of refinancing interest and positions rather than the option of getting rid of debt burden. That is exactly what happened in the cases of the East-Asian and US subprime crises.

At the international level, countries are distinguished between developed and developing, large economies, medium-sized and small. Thus, there is an asymmetry among them, which is also identified in terms of markets and institutions. Bearing in mind their global interaction, we deduct that any, even small, fluctuation in monetary policy or portfolio choices that stem from a large country will produce a significant impact on other countries and markets in relation to their size. The implication is that smaller economies and markets in an integrated financial system will meet difficulties to cope only by themselves any adjustment made by the large economy. Similarly, the emergence of a crisis does not have the same implications to all countries. When a financial crisis occurs in an advanced economy, like in the US, agents could turn to public bonds and treasuries, contributing indirectly to the country's fiscal expansion. Instead, in developing countries, such as the East Asian case, a crisis will result in capital outflows, rendering the remedy more complex. Most of the developing countries do not have the option to expand their fiscal policy due to their large government debts or markets' unwillingness to lend them. It is evident that developing countries remain more vulnerable, since their domestic currencies are in no use in foreign currency market for settling accounts, and present greater exchange rate volatility with respect to main currencies, sometimes for reasons beyond domestic control. Unfortunately, in developing countries, financial crises have the additional effects of exchange rate devaluations, due to balance of payments adjustment and a fiscal contraction. The above combination makes for developing countries the application of fiscal expansion as a crisis counteractive policy difficult.

We should also notice that financial crises have appeared because of the deregulation process some countries have adopted in their financial system. Innovations, securitization, speculations in foreign currencies, and banks' complex activities are also syndromes that contribute to financial instability. The underestimation of the possibility of a financial event is apparent, due to the myopic attitude of governments, bankers, investors, agents. Therefore, governments seem to be absent in terms of regulatory control. The deregulation mainly involved the distribution of bank loans and credit to insolvent agents and firms or to a larger group of borrowers with minimum criteria requirements. The abatement of regulation facilitates 
the creation of financial cycles, rendering the system more vulnerable and prone to crises. Minsky realized almost forty years ago that instability to the financial markets depends on their structure. He stated that the dynamic accumulating capitalist economy through the development of the financial system should be regulated. Thus, thwarting institutions, such as a big government and central bank, could guarantee the avoidance of financial risks and the stability of the financial system.

Finally, financial globalization alongside with speculation could entail serious economic consequences for a country, leaving it helpless, with no capacity to launch a single recovery policy with success or to defend itself from an international speculative attack. Whenever capital inflows and outflows are liberalized with no restrictions, then speculation is possible. Additionally, the initial euphoric phase is not helpful to acknowledge what will ensue. However, we could deduct, as a conclusion, that instability and crises are not simply unexpected events but endogenous cultivated phenomena within the globalized financial economy, since it is the function of the financial system that generates them.

However, the bottom line remains the transmission of each country's financial distortion to the international financial system. Financial integration and globalization have increased growth rate opportunities but risks likewise. A financial crisis originated from a country with high interdependence in terms of trade and financial transactions may become an overall and complex issue at the international level, unable to resolve it by its own means. That is the reason why many economists urge each state to take precaution measures to internalize their distortions at any level. However, regarding the degree of globalization, the interactions in terms of trade, free capital mobility and in some cases a monetary integration (such as the $\mathrm{EU}$ ), how could it be possible to isolate a financial event? Consequently, the world's financial stability and economy could be in peril. In spite of mutual benefits in prosperous periods, the flip side of the coin is the transmission of a crisis. Therefore, the solution lies with the creation of the problem. Since the simultaneous existing of all the above factors is apparent, then all institutions and governments become equal partners of a financial default whenever and wherever that might occur. Hence, all responsibility is to solve it in a common and fair manner.

\section{References}

1. Borio, C, Disyatat, P. (2011). Global imbalances and the financial crisis: link or no link?, BIS Working Papers no 346. Revised and extended version of Global imbalances and the financial crisis: Reassessing the role of international finance. Asian Economic Policy Review, No. 5/2010, pp. 198-216.

2. Borio, C. (2014). The international monetary and financial system: its Achilles heel and what to do about it. BIS Working Paper, No. 456, BIS.

3. Citanna, A., Schmedders, K. (2005). Excess price volatility and financial innovation. Article in Economic Theory, No. 26(3), pp. 559-587. 
4. Chote, R. (1998). Financial Crises and Asia. Centre for Economic Policy Research, Financial Crises and Asia, CEPR, Conference Report No. 6.

5. Eichengreen, B, Arteta, C. (2000). Banking crises in emerging markets: presumptions and evidence. Center for International and Development Economics Research, Working Paper, C00-11.

6. Frenkel, R. (2003). Globalization and financial crises in Latin America. CEPAL Review, No. 80, pp. 41-54.

7. Greenspan, A. (1998, September 23). The crisis in emerging market economies. Testimony of Chairman Alan Greenspan Before the Committee on the Budget, U.S. Senate, The Federal Reserve Board.

8. Hart, O.D. (1975, December). On the optimality of equilibrium when the market structure is incomplete. Journal of Economic Theory, Vol. 11, Iss. 3, pp. 418-443.

9. Keynes, J.M. (1980). Activities 1940-1944, Shaping the Post-War World: The Clearing Union. The Collected Writings of John Maynard Keynes, Royal Economic Society, Vol. XXV. London: MacMillan and Cambridge University Press.

10. Kindleberger, C.P., Aliber, R. (2005). Manias, Panics, and Crashes. New Jersey: John Wiley \& Sons.

11. Krugman, P. (1998). What happened to Asia? Mimeo. Cambridge, MA: Department of Economics, Massachusetts Institute of Technology.

12. Mastromatteo, G. Esposito, L. (2016). Minsky at Basel: A Global Cap to Build an Effective Post crisis Banking Supervision Framework. The Jerome Levy Economics Institute of Bard College, Working Paper No. 875, September 1992.

13. McKinnon, R.I., Pill, H.l (1997). Credible economic liberalizations and overborrowing. American Economic Review, No. 87(2), pp. 189-193.

14. Minsky, H.P. (1975). John Maynard Keynes. New York: Columbia University Press.

15. Minsky, H.P. (1986a). Stabilizing an Unstable Economy. New Haven: Yale University Press.

16. Minsky, H.P. (1986b). Where is the Cash Flow? Bard Digital Commons, Hyman P. Minsky Archive. Open access submission year 1986. Retrieved from: https://digitalcommons.bard. edu/hm_archive/98.

17. Minsky H.P. (1990). Schumpeter: finance and evolution. [In:] A. Heertje, M. Perlman (Eds.). Evolving Market Technology and Market Structure: Studies in Schumpeterian Economics. Ann Arbor: The University of Michigan Press.

18. Minsky, H.P. (1991). Financial crisis: Systemic or Idiosyncratic. The Jerome Levy Economics Institute of Bard College, Working Paper No. 51, pp. 2-29.

19. Minsky, H.P. (1992). The Financial Instability Hypothesis. The Jerome Levy Economics Institute of Bard College, Working Paper No. 74, pp. 1-9.

20. Minsky, H.P. (1993). Finance and Stability: The limits of Capitalism. Levy Economics Institute of Bard College, Bard Digital Commons, WP 93.

21. Mr. Greenspan draws lessons from the global crises of 1997 and 1998 (1999). Chairman of the Board of Governors of the US Federal Reserve System, before the World Bank Group and the International Monetary Fund, Program of Seminars, Washington, D.C., on 27 September 1999. BIS Review 101/1999, pp. 1-5.

22. Peterson, W.C. (1977). Institutionalism, Keynes and the real world. Journal of Economic Issues, No. 11(2), pp. 201-221. 
23. Sau, L. (2013). Instability and Crisis in Financial Complex Systems. Review of Political Economy, Universita degli Studi di Torino, pp. 1-14

24. Schumpeter, J.A. (1934). Theory of Economic Development. Cambridge: Mass. Harvard University Press.

25. Stiglitz, J. (2018, September). Ten Years Later. Roosevelt Institute Working Paper, pp. 1-23.

26. The Federal Reserve Board (1998, March 3), The current Asian crisis. Testimony of Chairman Alan Greenspan, Before the Subcommittee on Foreign Operations of the Committee on Appropriations.

27. The Federal Reserve Board (1998, January 30), The current Asia crisis and the dynamics of international finance, Testimony of Chairman Alan Greenspan, Before the Committee on Banking and Financial Services, U.S. House of Representatives.

28. Whalen, J.C. (2009). An Institutionalist Perspective on the Global Financial Crisis. New York: Cornell University, pp. 1-23

29. World Bank (1997). World Bank Annual report 1997. International Bank for Reconstruction and Development (IBRD) and the International Development Association (IDA). Washington DC: World Bank Publications.

30. Wray, R., Mazzucato, M. (2015). Financing the Capital Development of the Economy: A KeynesSchumpeter-Minsky Synthesis. Levy Economics Institute of Bard College Working Paper No. 837. 